\title{
Issues and Challenges of Solid Waste Management Practices in Port- Harcourt City, Nigeria- a behavioural perspective
}

\author{
Dr. M.O. Agwu, MNIM, MNISP \\ Department of Business Administration, Niger Delta University, Wilberforce Island, Bayelsa \\ State
}

\begin{abstract}
The paper examined the relationship between individual background (sex, age and social class) and the level of awareness, knowledge and practices of solid waste management in PortHarcourt city residents. It defines solid waste management as the process of collecting, storing, treatment and disposal of solid wastes in such a way that they are harmless to humans, plants, animals, the ecology and the environment generally. The objective of this research is to ascertain the relationship between individual background (sex, age and social class) and the level of awareness, knowledge and practices of solid waste management in Port-Harcourt city residents. The research question addressed the extent of relationship between individual background (sex, age and social class) and the level of awareness, knowledge and practices of solid waste management in Port-Harcourt city residents. This research is based on Ajzen (1991) theory of planned behaviour which states that attitude towards behaviour, subjective norm, and perceived behavioural control, has influence in predicting the behavioural intention and actual behaviour of individuals when participatory decisions are voluntary and under an individual control. The research assumes that the background (sex, age and social class) of Port-Harcourt city residents influences their attitude, subjective norm and perceived behavioural control thus determining the behavioural intention/actual behaviour i.e. level of awareness, knowledge and practices of solid waste management. 800 Port-Harcourt city residents were randomly surveyed from the two local government areas of the city (Port-Harcourt city and Obio/Akpor LGAs) using structured questionnaire. Data collected were subjected to percentage, mean, standard deviation, t-test and chi-square statistical analyses. Findings revealed that Port-Harcourt city residents from the sampled zones are aware of solid waste management problems in their environment but possessed poor waste management practices. The study showed that the propensity for solid waste management practices differed by background (sex, social class and age) of residents. Significant relationships were observed between respondents' sex, age and social class and their level of awareness, knowledge and practices of solid waste management. This research therefore recommends among others: sensitization of Port-Harcourt city residents on the dangers of poor solid waste management, provision of near-by solid waste collection points, enactment of waste management laws with stiffer penalties on offenders, establishment of solid waste recycling plants, effective monitoring of waste contractors, provision of more waste evacuation equipment, provision of more solid waste dump sites and effective monitoring of monthly clean-up activities.
\end{abstract}

Keywords: Solid waste management, knowledge, Practices, Individual background, PortHarcourt city residents.

\section{INTRODUCTION}

Nigeria's major urban cities including Port-Harcourt are today fighting to clear mounting heaps of solid waste from their environments. These strategic centers of beauty, peace and security are being overtaken by the messy nature of over flowing dumps, unattended heaps of solid wastes emanating from household or domestic or kitchen sources, markets, shopping and business centers. PortHarcourt city environmental officials/waste contractors appear unable to combat unlawful and haphazard dumping of solid wastes on the streets and drainages, which are a clear violation of the Rivers state clean Air and Health Edict of 1990. Solid wastes comprise all the wastes arising from human and animal activities that are normally solid, discarded as useless or unwanted. Also included are 
by- products of process lines or materials that may be required by law to be disposed of (Okecha, 2000).

Solid wastes have become recurring features in our urban environment. It is no longer in doubt that our cities are inundated with the challenges of un-cleared solid wastes. Thus, urban residents are often confronted with the hazardous impact to their collective health and safety. The hue and cry over the health consequences of exposed and fermenting rubbish have not been quantified, although their impact is noticeable. A United Nations Report (August 2004) noted with regret that while developing countries are improving access to clean drinking water they are falling behind on sanitation goals(Uwaegbelun, 2004). At one of its summit in 2004, the World Health Organization and the United Nations International Children Education Fund in a joint report stated that: "about 2.4 billion people will likely face the risk of needless disease and death by the year 2015 because of bad sanitation". The report also noted that bad sanitation - decaying or nonexistent sewage system and toilets- fuels the spread of diseases like cholera and basic illness like diarrhea, which kills a child every 21 seconds. The hardest hit by bad sanitation is the rural poor and residents of slum areas in fast-growing cities, mostly in Africa and Asia.

Solid waste management is the process of collecting, storing, treatment and disposal of solid wastes in such a way that they are harmless to humans, plants, animals, the ecology and the environment generally. The unhealthy disposal of solid waste is one of the greatest challenges facing developing countries (Kofoworola, 2007). It is a problem recognized by all nations at the 1992 Conference on Environment and Development, and regarded as a major barrier in the path towards sustainability (UNCED, 1992). Hence, individual/group awareness and attitude towards solid waste generation and disposal is critical in the effort to combat the current solid waste management challenges in Port-Harcourt city. It is against this background that it becomes pertinent to examine whether there is a relationship between individual background (sex, age and social class) and the level of awareness, knowledge and practices of solid waste management in Port-Harcourt city residents.

Statement of the Problem: Indiscriminate solid waste disposal is actually a menace and embarrassment to Port-Harcourt city (the Garden city) where heaps of refuse litter most parts of the city (Isu, 2005).Considerable percentage of solid wastes generated in Port-Harcourt city are either deposited on the roads, or road sides, unapproved dump sites, in water ways (drainage system), or in open sites which adversely affect environmental friendliness. In fact, solid waste poses various threats to public health and adversely affects flora and fauna as well as the environment especially when it is not appropriately collected and disposed (Geraldu, 1995). The poor state of solid waste management in Port-Harcourt city is caused by inadequate facilities, poor funding, and poor implementation of policies as well as wrong lifestyle (consumption pattern). According to Egunjobi (1986), the problem of effective solid waste management has to do with poor social services delivery efforts which cause unnecessary delays in solid waste clearance. It is either broken down machinery, non-maintenance of dumpsters, poorly maintained urban streets and roads and irregularities in the designation of sanitary landfill sites. Nigerians seem to be permanently accustomed to dirt. Evidence of this can be seen every day by way of indiscriminate discharge of garbage into drains and at times on the highways. Studies have revealed that household account for about half of the solid wastes generated, that is, by weight in the third world cities, which includes PortHarcourt. It has also been noted that solid waste management has received considerable attention not only in Rivers State but Nigeria generally.

Despite this laudable attention, collection, disposal processing, treatment, recycling and utilization have defied solution as a result of the attitude of some Nigerians. It is believed that the waste disposal habit of the people, corruption, work attitude, inadequate plants and equipment among others are the major factors militating against effective solid waste management in Port-Harcourt city. The major effects of poor solid waste management in Port-Harcourt city include: blocked drains, flooding, erosion, traffic congestion, soil pollution, air pollution, health problems, unaesthetic dump sites and loss of community pride.

Research Objectives: The objectives of this research are as follows:

1. To ascertain the level of awareness of PortHarcourt city residents of the solid waste management problems in their environment.

2. To ascertain if there is any significant difference between background (sex, age and social class) and level of awareness, knowledge and practices of solid waste management in Port-Harcourt residents. 
Research Questions: From the above objectives, the following research questions are hereby formulated:

1. To what extent are Port-Harcourt city residents aware of the solid waste management problems in their environment?

2. Is there any significant difference between background (sex, age and social class) and level of awareness, knowledge and practices of solid waste management in Port-Harcourt residents?

Research Hypotheses: From the above research questions, these null and alternative hypotheses are formulated:

$\mathbf{H}_{\mathrm{o}}$ : There is no significant difference between background (sex, age and social class) and the level of awareness, knowledge and practices of solid waste management in Port-Harcourt city residents.

$\mathbf{H}_{1}$ : There is a significant difference between background (sex, age and social class) and the level of awareness, knowledge and practices of solid waste management in Port-Harcourt city residents.

Many studies in the last two decades on sociodemographic variables and environmental perception have helped in understanding people's views, and thinking about the environment. They have attempted to predict environmental awareness and attitudes of people based on their socio-demographic characteristics. For instance, Raudsepp (2001) reported that age, education and gender have shown strong and consistent relationship with environmentalism. Other researchers (Mensah \& Whitney, 1991; Gigliotti, 1992 and Sheppard, 1995) have attempted to ascertain the correlates of environmental knowledge and environmental quality awareness and concern. Some others have also explored the influence of education, income, age, and gender on public awareness and attitude toward environmental quality issues. Chanda (1999) reported that environmental concerns among residents of Gaborone vary according to education and income levels, while age and gender do not seem to have any significant influence on the concerned variation.

Gender is a variable that has received consistent attention among researchers (Jones \& Dunlap, 1992; Arcury \& Christianson, 1993 and Petts, 1994). Raudsepp (2001) found that women were significantly more likely than men to be concerned with environmental problems. Females have been consistently shown to have higher environmentally conscious attitudes than men. The common reason advanced for gender differences is the different socialization patterns between boys and girls. More often than not, girls are made to carry out most of all the sweeping and cleaning activities; they are called upon more than their male counterparts to perform maintenance tasks at home or in schools.

However, in other studies such as Van Liere \& Dunlap (1981) gender was not a significant predictor of environmental concerns and attitudes as other socio-demographic variables. Eagle \& Demare's (1999) comparison of the mean attitude scores on the pretest with gender showed that girls scored significantly higher moral attitude scores than boys; there was no significant difference in the ecologic attitude scores of boys and girls. Kellert (1985) found no gender difference in these two attitudes for U.S. children in the 2nd grade. Eagles and Muffitt (1990), in a study of Canadian students in 6th, 7th, and 8th grade, found no attitude differences between the sexes.

Onokerhoraye (1977) in his study related the issue of the decomposing un-cleared solid wastes in our urban centers to lack of comprehensive land use system which extols the values of urban planning and environmental quality. $\mathrm{He}$ asserted that poorly maintained winding streets and roads do not give room for the efficient evacuation of solid wastes to incineration centers at the outskirts of cities. The observation of these proponents of environmental sanitation leads to only one conclusion - that rapid urbanization has resulted in inadequate responses to the dumping of refuse along city streets, in burrows or erosion impacted terrains, and river beds or flood basins. These features of indiscriminate waste dumping reduce invariably the capacity of the rivers and rivulets to dispose storm runoffs along their drainage channels.

There are studies that have examined public, households and students "knowledge and attitudes towards waste management (e.g. Barr, Gilg \& Ford, 2001; Meyers, Glen \& Anbarci, 2006). Bassey, Benka-Coker and Aluyi (2006) used both qualitative and quantitative methods to examine the types of and waste disposal techniques employed in the management of solid medical wastes in five selected hospitals in the Federal Capital Territory, Abuja and reported that an average of $2.78 \mathrm{~kg}$ of solid waste were generated per bed/daily. In addition, $26.5 \%$ of the total waste was found to be hazardous in nature. No separation of waste was practised by any of the hospitals surveyed. 
Similarly, $18.3 \%$ of the hospitals incinerated waste was traced to a locally built brick incinerator; $9.1 \%$ buried; $36.3 \%$ burnt waste in open pits while $36.3 \%$ disposed waste in municipal dumpsites. Sha'Ato, Aboho, Oketunde, Eneji, Unazi \& Agwa, (2007) also found that a substantial proportion of household waste consists of various organic materials (36-57\%), while ash, dust and sand (combined) constitute between $(21-41 \%)$. There was more paper from commercial and institutional premises $(9-12 \%)$ than from household or small/medium scale industrial premises (2-4\%). Glass (0.1-6.9\%), metals (mostly cans and bottle taps, 0.7-3.4\%) and textiles (0.3-6\%) constitute minor proportion of the waste across the sampled areas. The study also reported that households daily generated $0.54 \mathrm{~kg}$ waste; 0.018 $\mathrm{kg} / \mathrm{m} 2 /$ day by commercial outlets; while small and medium scale industries, generated $0.47 \mathrm{~kg} / \mathrm{m} 2 /$ day.

Conceptual Framework: Solid waste management is the process of collecting, storing, treatment and disposal of solid wastes in such a way that they are harmless to humans, plants, animals, the ecology and the environment generally. Solid waste can be defined as "any substance or object in solid form which the holder discards or intends to discard" (Waste Framework Directive 75/442/EEC, 1975, Article 1 (a)). The 'holder' can either be the producer of the waste or be in possession of the waste (Williams, 2005). Waste, however, is very subjective; one person may deem an item to be waste whilst another might see it as a resource (Williams, 2005). The way solid waste is managed for different types of sectors is important as the nature of each industry or sector varies. The dynamic nature of consumer/end user products, packaging materials, environmental regulations and public attitudes has made the development of solid waste management strategies an increasingly complex task (Sakai et al, 1996).

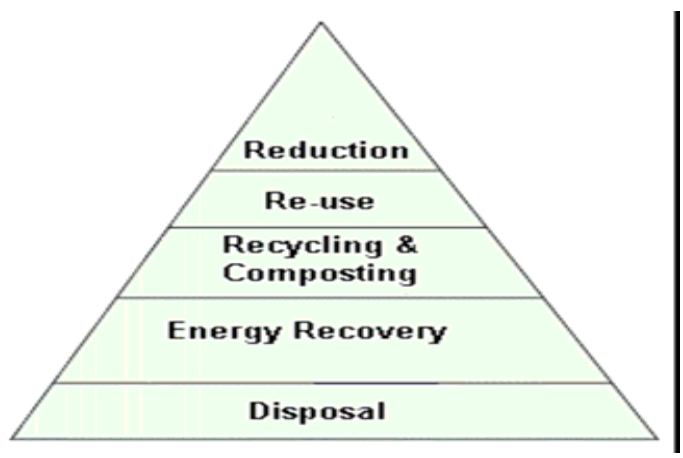

Fig. 1 'waste hierarchy'
The existing UK waste management concept is derived from EU waste policy known as the 'waste hierarchy' (illustrated in Figure 1). Due to over reliance on landfill that caused shortages of landfill sites in the UK. In 1996, UK government waste directives and the National Waste Strategy were introduced to monitor, suggest, support and implement ways to reduce waste disposal. The new reduction targets imposed on commercial and industrial solid wastes in landfill sites is set at least $20 \%$ reduction by 2010 compared to 2004 target (DEFRA, 2007).

\section{Theoretical Framework}

This research is based on Ajzen (1991) theory of planned behaviour as shown in figure 2 below:

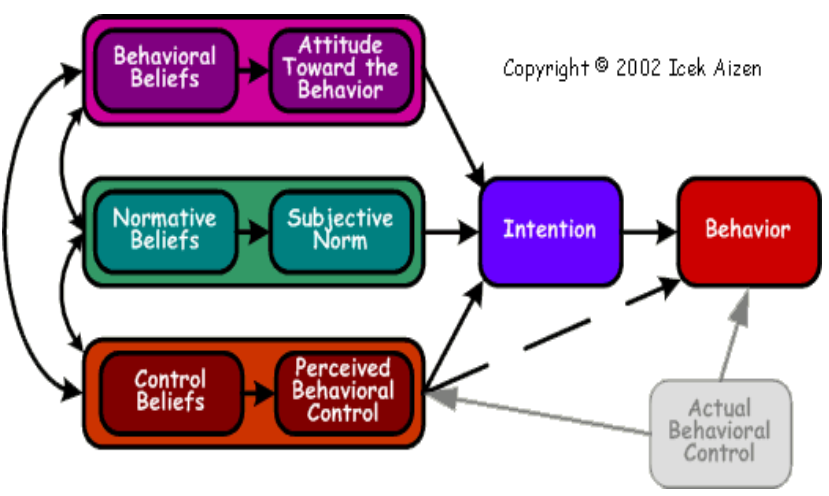

Source: Ajzen, I. (1991). The theory of planned behaviour. Organizational Behavior and Human Decision Processes, 50, p. 179-211.

The Theory of Planned Behaviour (TPB) states that an individual's behavioural beliefs, normative beliefs and control beliefs respectively determine his/her attitude towards a given behaviour, subjective norm, and perceived behavioural control, which collectively influence the behavioural intention and actual behaviour of the individual when participatory decisions in an action are voluntary and under an individual's control. The research assumes that the background (sex, age and social class) of PortHarcourt city residents influences their attitude, subjective norm and perceived behavioural control thus determining the behavioural intention/actual behaviour i.e. level of awareness, knowledge and practices of solid waste management.

Legal Framework: Sustainable waste management is the ultimate goal of any piece of waste legislation produced today. The practical achievement of this 
goal is, however, more difficult than its theoretical consideration. Local authorities, who bear the brunt of meeting targets and implementing strategies, need guidelines to help them sustainably achieve the targets.

The mountainous heaps of solid wastes that deface Nigerian cities and the continuous discharge of industrial contaminants into streams and rivers without treatment motivated the federal government of Nigeria to promulgate Decree 58 for the establishment of Federal Environmental Protection Agency (FEPA) on 30 December 1988 (Federal Military Government 1988). A national policy on the environment was formed and the goals of the policy include: to secure for all Nigerians a quality of environment adequate for their health and wellbeing; to raise public awareness and promote understanding of the essential linkages between the environment and development; and to encourage individual and community participation in environmental protection and improvement efforts (FEPA 1989). As regards the solid waste sector, the specific actions desired include collection and disposal of solid waste in an environmentally safe manner; setting up and enforcement of laws, regulations, and standards; encouragement of public participation; environment monitoring and imposition of penalties on defaulters to encourage compliance (FEPA 1989; FRN 1991).

Over recent years, legislations have been passed by the European Union (EU), and implemented in the U.K., to help tackle the menace of solid waste in the country. Examples include, the Waste Landfill Directive 99/31/EC, the Waste Incineration Directive 2000/76/EC, the Packaging Waste Directive 94/62/EC, and the Waste Electrical and Electronic Equipment 2002/96/EC. The Waste Landfill Directive 99/31/EC sets the target for decreasing the amount of biodegradable material that ends up in landfill in member states to $75 \%$ of 1995 levels by $2006,50 \%$ of 1995 levels by 2009, and 35\% of 1995 by 2016 (Williams, 2005). In addition, the Directive states that solid waste should be treated before being taken to landfill, by physical, thermal, chemical or biological processes and that diversion away from landfill is the preferred option (Williams, 2005).

The Waste Incineration Directive 2000/76/EC, sets stringent operational conditions, technical requirements and emission-limit values for incinerators, to achieve its overall aim of a high level of environmental and human health protection (Williams, 2005). If an incinerator does not attain the required standard, it will be shut down until it does (Bell and McGillivray, 2000). The Packaging Waste Directive 94/62/EC aims at preventing the production of packaging waste and encourages its recycling, reuse and recovery (Bell and McGillivray, 2000). In addition, it aims at increasing the use of recycled packaging materials, and to increase the use of innovative design, allowing products to be designed and packaged in such a manner that permits packaging re-use and recovery (Waste Online, 2004c). The Waste Electrical and Electronic Equipment 2002/96/EC aims at promoting the reuse, recycling and recovery of electrical and electronic wastes and in doing so, to reduce the amount of solid wastes produced (Williams, 2005). The Directive also aims at improving the environmental performance of operators involved in the lifecycle of electrical and electronic goods (Waste Online, 2004c).

Research Methodology: The research is a descriptive cross-sectional survey of randomly selected Port-Harcourt city residents using wellstructured questionnaire for the purpose of primary data collection on the level of awareness, knowledge and practices of solid waste management in PortHarcourt city. The questionnaire was validated using test-re-test technique while a pilot survey was conducted using 60 randomly selected Port-Harcourt city residents from the two local government areas (Port-Harcourt city and Obio/Akpor LGAs') that constitute the city metropolis. Coefficient of internal consistency of the questionnaire was calculated using the Kudar Richardson ( $\mathrm{Kr} 21)$ formula. The reliability coefficient of the research instrument obtained was 0.82 . A total of eight hundred PortHarcourt city residents were surveyed from different ages, sex and social class. One hundred and fifty (150) respondents wrongly completed their questionnaire and were subsequently cancelled. However, only six hundred and fifty of the returned questionnaires (that is 72 . 2 percent) were found to be properly completed and were used for the analysis.

Data Analysis: The statistical methods used in this research consisted of descriptive statistics of frequency count, percentage, mean and standard deviation. Other statistical methods employed included Chi-square, t-test and Pearson product moment correlation in order to determine the significant difference or relationship between PortHarcourt city residents' background variables and their level of awareness knowledge and practices of solid waste management. Responses to the 
questionnaire were pooled, edited and scored. Nominal values were assigned to the items according to scales. Questions on knowledge and awareness had an assigned score of 1-4 for -Not surell, Not Worried\| -Worried\| - Very Worriedll. To determine the partitioning value of items, the maximum of each of the nominal values was divided by $\mathrm{N}$. Thus, the upper limit of knowledge/awareness was put at 2.50, while for practices was put at 1.50. For purposes of data interpretation, mean values of 2.50 and above were deemed to indicate high knowledge/awareness and below 2.50 were regarded as implying low. Mean values of 1.50 and above were considered for positive practice. A standard deviation greater than
1.00 was taken to indicate high variability among respondents.

\section{RESULTS AND DISCUSSION}

The sample $(n=650)$ consisted of $267(41 \%)$ males and $383(59 \%)$ females Port-Harcourt city residents. They had ages of below and above 25years. A fourpoint scale was used as a self-measure of PortHarcourt city residents' awareness. The data in Table 1 shows that all the mean scores for the items that measure awareness were above the midpoint (2.50) set. The findings suggest that Port-Harcourt city residents are aware of the solid waste management problems in their environment.

\section{Table 1: Mean and standard deviation on responses of Port-Harcourt city residents level of Awareness}

\begin{tabular}{|c|c|c|c|c|c|c|}
\hline Questions & Not Sure & Not Worried & Worried & Very Worried & Mean & $\begin{array}{l}\text { Standard } \\
\text { Deviation(SD) }\end{array}$ \\
\hline $\begin{array}{l}\text { To what } \\
\text { extent do you } \\
\text { worry about } \\
\text { solid wastes } \\
\text { in your } \\
\text { environment? }\end{array}$ & $\begin{array}{l}5 \\
(0.8)\end{array}$ & $\begin{array}{l}170 \\
(26.2)\end{array}$ & $\begin{array}{l}187 \\
(28.8)\end{array}$ & $\begin{array}{l}288 \\
(44.3)\end{array}$ & 3.17 & 0.84 \\
\hline $\begin{array}{l}\text { How } \\
\text { interested } \\
\text { would you } \\
\text { say are in } \\
\text { solid wastes } \\
\text { in your } \\
\text { environment? }\end{array}$ & $\begin{array}{l}\text { Not Sure } \\
\\
37 \\
(5.7)\end{array}$ & $\begin{array}{l}\text { Not Interested } \\
\\
235 \\
(36.2)\end{array}$ & $\begin{array}{l}\text { Interested } \\
\\
141 \\
(21.7)\end{array}$ & $\begin{array}{l}\text { Very } \\
\text { Interested } \\
\\
237 \\
(3.5)\end{array}$ & 2.89 & 0.97 \\
\hline $\begin{array}{l}\text { How } \\
\text { important do } \\
\text { you regard } \\
\text { the way your } \\
\text { neighbours } \\
\text { do away with } \\
\text { solid wastes? }\end{array}$ & $\begin{array}{l}\text { Not Sure } \\
\\
104 \\
(16.0)\end{array}$ & $\begin{array}{l}\text { Not Important } \\
160 \\
(24.6)\end{array}$ & $\begin{array}{l}\text { Important } \\
\\
165 \\
(25.4)\end{array}$ & $\begin{array}{l}\text { Very } \\
\text { Important } \\
\\
221 \\
(34.0)\end{array}$ & 2.77 & 1.08 \\
\hline $\begin{array}{l}\text { Are you } \\
\text { satisfied with } \\
\text { the way } \\
\text { neighbours } \\
\text { dispose their } \\
\text { solid wastes? }\end{array}$ & $\begin{array}{l}\text { Very } \\
\text { Dissatisfied } \\
-\end{array}$ & $\begin{array}{l}\text { Dissatisfied } \\
363 \\
(55.8)\end{array}$ & $\begin{array}{l}\text { Satisfied } \\
216 \\
(33.2)\end{array}$ & $\begin{array}{l}\text { Very Satisfied } \\
71 \\
(10.9)\end{array}$ & 2.55 & 0.68 \\
\hline $\begin{array}{l}\text { How satisfied } \\
\text { are with the } \\
\text { way solid } \\
\text { wastes are } \\
\text { handled by } \\
\text { Port-Harcourt } \\
\text { city waste } \\
\text { contractors? }\end{array}$ & $\begin{array}{l}\text { Very } \\
\text { Dissatisfied } \\
11 \\
(1.7)\end{array}$ & $\begin{array}{l}\text { Dissatisfied } \\
\\
323 \\
(49.7)\end{array}$ & $\begin{array}{l}\text { Satisfied } \\
\\
185 \\
(28.5)\end{array}$ & $\begin{array}{l}\text { Very Satisfied } \\
131 \\
(20.02)\end{array}$ & 2.67 & 0.81 \\
\hline
\end{tabular}


Using percentages, the item-by-item analysis further reveals that only $26.2 \%$ of the respondents claimed not worried about the solid waste around their environment, $44.3 \%$ and $28.8 \%$ gave very worried and worried responses respectively. More than $59.4 \%$ acknowledged their interest in solid waste management in their environment while $36.2 \%$ of the respondents also reported that they placed great importance on the way their neighbours dispose solid waste. $34.0 \%$ of the respondents stated -very importantll, (33.2\%) -important\|, $24.6 \%$-not importantll, while $16.0 \%$ were not sure. More than half $(55.8 \%)$ of the respondents expressed dissatisfaction with the way solid wastes are disposed within their environment, $33.2 \%$ said they are satisfied, while only $10.9 \%$ are very satisfied with the way wastes are disposed within their environment. On how satisfied they are with the way solid wastes are handled by the waste contractors in Port-Harcourt city, $20.2 \%$ responded very satisfied, $28.5 \%$ satisfied and $49.7 \%$ and $1.7 \%$ dissatisfied and very dissatisfied respectively.

In order to establish the demographic correlation of the solid waste management variables, some demographic characteristics of Port-Harcourt city residents presumed to possibly have a measure of influence on the awareness, knowledge and practices of solid waste management were calculated: Pearson correlation $(r)$ and Chi-square $\left(x^{2}\right)$. The results obtained are summarized in Table 2 and 3.

Table 2: Test of significant difference in Port-Harcourt city residents' awareness, knowledge and practices of solid waste management

\begin{tabular}{|c|c|c|c|c|c|c|c|c|c|c|c|c|}
\hline \multicolumn{5}{|c|}{ Awareness } & \multicolumn{4}{|c|}{ Knowledge } & \multicolumn{4}{|c|}{ Practices } \\
\hline Sex & Mean & SD & $t$ & Sig. & Mean & SD & $\mathbf{t}$ & Sig. & Mean & SD & $\mathbf{t}$ & Sig. \\
\hline Male & 20.70 & 2.63 & 3.73 & 000s & 15.50 & 4.05 & -.327 & $.744 n s$ & 27.23 & 4.40 & -3.84 & 000s \\
\hline Female & 19.81 & 3.16 & & & 15.60 & 4.17 & & & 28.50 & 3.92 & & \\
\hline $\begin{array}{l}\text { Social } \\
\text { Class } \\
\text { Lower } \\
\text { class }\end{array}$ & 20.07 & 2.80 & -.848 & $.397 n s$ & 15.90 & 4.00 & 1.98 & 0.048 & 27.11 & 4.44 & -5.01 & 000s \\
\hline $\begin{array}{l}\text { Upper } \\
\text { class }\end{array}$ & 20.27 & 3.13 & & & 15.26 & 4.23 & & & 28.72 & 3.74 & & \\
\hline $\begin{array}{l}\text { Age } \\
\text { Below } \\
\text { 25years }\end{array}$ & 20.22 & 3.01 & .521 & $.602 \mathrm{~ns}$ & 16.22 & 4.03 & 5.03 & 000s & 27.57 & 4.35 & -2.91 & $.004 \mathrm{~s}$ \\
\hline $\begin{array}{l}\text { Above } \\
25 y e a r s\end{array}$ & 20.10 & 2.92 & & & 14.60 & 4.07 & & & 28.53 & 3.79 & & \\
\hline
\end{tabular}

* Significant at the 0.05 level

Table 2 suggests that male Port-Harcourt city residents had significantly higher awareness scores for each of the item than the females, while the female residents could be said to have positive solid waste management practices than their male counterparts. This is plausible when one considers the fact that in most households in developing countries females do most of the cleaning and sweeping activities. No significant differences were observed in Port-Harcourt city residents' knowledge and awareness according to social class. However, there was a significant difference in their practices of solid management. With respect to age, PortHarcourt city residents' differed significantly in knowledge and practices. Port-Harcourt city residents below 25 years of age have significantly higher knowledge of waste management than those above 25 years of age. On practice, the reverse was the case; as Port-Harcourt city residents above 25 years of age had higher scores for each of the items than those below 25 years of age. 
Am. J. Soc. Mgmt. Sci., 2012, 3(2): 83-92

Table 3: Test of Significant relationship between Port-Harcourt city residents' awareness, knowledge and practices of solid waste management

\begin{tabular}{|l|l|l|l|l|l|l|l|l|l|}
\hline \multicolumn{9}{|l|}{ Awareness } & \multicolumn{3}{l|}{ Knowledge } & \multicolumn{2}{l|}{ Practices } \\
\hline & $\mathrm{X}^{2}$ & $\mathrm{df}$ & Sig. & $\mathrm{X}^{2}$ & $\mathrm{df}$ & Sig. & $\mathrm{X}^{2}$ & $\mathrm{df}$ & Sig. \\
\hline Sex & 100.67 & 15 & $.000 \mathrm{~s}$ & 106.62 & 21 & $.000 \mathrm{~s}$ & 74.56 & 23 & $.000 \mathrm{~s}$ \\
\hline Age & 76.71 & 15 & $.000 \mathrm{~s}$ & 60.67 & 21 & $.000 \mathrm{~s}$ & 92.31 & 23 & $.000 \mathrm{~s}$ \\
\hline Class & 69.24 & 15 & $.000 \mathrm{~s}$ & 86.09 & 21 & $.000 \mathrm{~s}$ & 83.67 & 23 & $.000 \mathrm{~s}$ \\
\hline
\end{tabular}

${ }^{*}$ Significant at the 0.05 level

The chi-square analysis presented in Table3, demonstrates that significant relationship exists between Port-Harcourt city residents' background variables and awareness, knowledge and practice.

What this suggests is that Port-Harcourt city residents' awareness, knowledge and practices are related to their personal characteristics.

Table 4: Correlation between Port-Harcourt city residents' background variables and awareness, knowledge and practices of solid waste management

\begin{tabular}{|c|c|c|c|c|c|c|}
\hline Variables & Sex & Age & Social Class & Awareness & Knowledge & Practices \\
\hline Sex & 1 & & & & & \\
\hline Age & .018 & 1 & & & & \\
\hline Social Class & $.122\left({ }^{* *}\right)$ & $.487\left(^{* *}\right)$ & 1 & & & \\
\hline Awareness & $-.145\left(^{* \star}\right)$ & -.020 & .033 & 1 & & \\
\hline Knowledge & .013 & $-.194\left({ }^{\star \star}\right)$ & $-.078\left(^{\star}\right)$ & .064 & 1 & \\
\hline Practices & $.149\left(^{* *}\right)$ & $.114\left(^{* *}\right)$ & $\left..193^{(* *}\right)$ & $\left.-.088^{*}\right)$ & -.065 & 1 \\
\hline
\end{tabular}

${ }^{* *}$ Correlation is significant at the 0.01 level (2-tailed). ${ }^{*}$ Correlation is significant at the 0.05 level (2-tailed).

Data in Table 4 reveals that a positive and significant $>$ association exists between solid waste management practices and some of the city residents background variables such as sex $(r=.149, p<0.05)$, age $(r=$ $.114, p<0.05)$ and social class of Port-Harcourt city residents' $(r=.194, p<0.05)$.

In addition, the results further shows a negative correlation between awareness and practice $(r=-$ $.088, p<0.05)$. A negative correlation is found between age and knowledge $(r=-.194, p<0.05)$; social class shows negative correlation with knowledge $(r=-.078, p<0.05)$. There is negative correlation between sex and awareness $(r=-.145)$.

Summary of Findings: This study sought to establish a baseline of descriptive information on Port-Harcourt city residents' knowledge, attitudes and practices concerning solid waste management in their environment. The findings of the research include:
Solid waste management is a serious environmental problem in Port-Harcourt city and the residents are aware of it. The is supported by Chan's (1998) report that people's environmental knowledge was highly specific to issue and geographic scale.

Port-Harcourt city residents' waste management practices depicted a negative practice. This supported by Duan and Fortner (2005) observed that people possessed high environmental awareness and knowledge of local environmental issues than global environmental issues.

Differences were observed in Port-Harcourt city residents' knowledge and practices of solid waste management. This is inconsistent with previous research (Van Liere \& Dunlap 1981; Kellert 1985; Eagles \& Muffitt, 1990; Palmer, 1995 and Raudsepp, 2001). According to Van Liere and Dunlap (1981) study, gender is not a significant predictor of environmental concerns and attitudes as other sociodemographic variables. 
Am. J. Soc. Mgmt. Sci., 2012, 3(2): 83-92

> This research also found correlation between respondents' knowledge and practices of waste management. This result found enormous support with previous studies (Jones \& Dunlap 1992 and Raudsepp, 2001), who has documented some relationship between some socio-demographic variables such as sex, age, and education and environmental behavior/practices.

> It was also observed that the propensity for solid waste management practices tend to differ by sex, social class and age of respondents. Significant relationships were observed between Port-Harcourt city residents' sex, age and social class and their level of awareness, knowledge and practices of solid waste management.

Conclusion: The findings of this research has great implications for the improvement of the current solid waste management practices in Port-Harcourt city in particular and in Rivers State in general where there is a need for behavioural and attitudinal change in achieving solid waste reduction, reuse and recycling for sustainable environmental management.

\section{Recommendations}

In view of the above conclusion, the following recommendations/suggestions are hereby made:

- Sensitization of Port-Harcourt city residents on the dangers of poor solid waste management.

- Provision of near-by solid waste collection points with segregation facilities to enhance easy collection and disposal of solid wastes from households.

* Enactment of waste management laws with stiffer penalties on offenders to ensure compliance.

* Establishment of solid waste recycling plants to reduce the quantity of solid wastes generated.

- Effective monitoring of waste contractors to ensure that their performance is up to expectation.

* Provision of more waste evacuation equipment and maintenance of existing ones.

- Provision of more landfill sites for disposal of biodegradable solid wastes.

- Effective monitoring of monthly clean-up activities to ensure general participation.

* Provision of incinerators for conversion of solid wastes into ash.

* Conduction of town hall meetings to educate members of the public on proper solid management.

* Appointment of sanitary/health inspectors for the supervision of solid waste management at the household level in Port-Harcourt city metropolis.

\section{REFERENCES}

Ajzen, I. (1991). The theory of planned behavior. Organizational Behavior and Human Decision Processes, 50, p. 179-211.

Arcury, T. A., \& Christianson, E. H. (1993). Rural-Urban differences in environmental knowledge and actions. Journal of Environmental Education, 25(1), 19-25.

Barr, S., Gilg, A. W., \& Ford, N. J. (2001). A conceptual framework for understanding and analysing attitudes towards household-waste management. Environment and Planning, 33, 2025-2048.

Bassey, B. E., Benka-Coker, M. O., \& Aluyi, H. A. S. (2006). Characterization and management of solid medical wastes in the Federal Capital Territory,Abuja Nigeria. African Health Sciences,6(1),58-63.

Bell, S. and McGillivray, D. 2000. Environmental Law, Fifth edition, Oxford University Press, Oxford, 726pp.

Chan, K. (1999). Mass communication and proenvironmental behaviour: waste recycling in Hong Kong. Journal of Environmental Management, 52, 3545.

Chanda, R. (1992). Correlates and dimensions of environmental quality concern among residents of an African Subtropical City: Gaborone, Botswana Journal of Environmental Education, 30(2), 31-39.

DERFA (2007). Waste Strategy for England 2007, Department for Environment, Food and Rural Affairs.

Duan, H., \& Fortner, R.W. (2005). Chinese college students' perception about global versus local environmental issues. Journal of Environmental Education, 36(4), 23-32.

Egunjobi, T.O (1986). Problems of solid wastes management in Nigeria urban centres. In: EA. Adeniyi, IB Bellow Imam (Eds.): Proceedings of National Conference on Development and Environment. Ibadan: NISER, pp. 74-92.

FEPA 1998 (Federal Environmental Protection Agency). 1989. National Policy on the Environment. Nigeria: FEPA, P. 22.

FRN (Federal Republic of Nigeria) 1991. Official Gazette 78 (42): B15 - B37.

Federal Military Government 1988. Federal Environmental Protection Agency Decree No. 58: A 911 - A 932.

Geradu, J. (1995). Spatial planning and the environment, IPC 681, The Netherlands Ministry of Hunsing 2024pp.

Gigliotti, L. M. (1992). Environmental attitudes: 20 years of change? The Journal of Environmental Education, 24(1), 15-26. 
Jones, R. E., \& Dunlap, R. E. (1992). The social bases of environmental concern. Have they changed over time? Rural Sociology, 57(1), 134-144.

Isu, B. A. (2005) The pains of waste .A Paper presented at the workshop organized by committee on vital Environmental Resources for Teachers/ Students, Eghosa Anglican Grammar School, Benin City, 1-6pp

Kellert, S. R. (1985). Attitudes toward animals: Age-related development among children. The Journal of Environmental Education, 16(3), 29-39.

Kofoworola, O. F. (2007). Recovery and recycling practices in municipal solid waste management in Lagos, Nigeria. Waste Management, 27 (9), 1139-1143.

Mensah, J., \& Whitney, H. A. (1991). Some Third World environmental perceptions and behaviours concerning urban waste: A survey of Techniman, Ghana. The Canadian Geographer, 35(2), 156-165.

Meyers, G. D, Glen McLeod., \& Anbarci, M. A. (2006). An international waste convention: measures for achieving sustainable development. Waste Management \& Research, 24(6), 505-513.

Eagle, P. F. J., \& Demare, R. (1999). Factors Influencing Children's Environmental Attitudes. Journal of Environmental Education, 30(4), 33-35.

Eagles, P. F. J., \& Muffitt, S. (1990). An analysis of children's attitudes toward animals. The Journal of Environmental Education, 21(3), 41-44.

Okecha, S.A. (2000). Pollution and Conservation of Nigeria Environment. T Afrique International

Associates Owerri Nigeria.

Onokerhoraye, A.G (1977). Public involvement in urban development planning: The case of environmental development planning sanitation in Ibadan, Nigeria. Journal of Administration Overseas. 10:171 - 177.

Packaging Waste Directive. 1994. Council Directive 94/62/EC, Official Journal of the European Communities, L 365, 10-23.

Petts, J. (1994). Effective waste management: Understanding and dealing with public concerns. Waste Management \& Research, 12(3), 207-222.

Raudsepp, M. (2001). Some socio-demographic and sociopsychological predictors of environmentalism. TRAMES, 5(4), 355-367.
Sakai S. et al (1996). "World trends in municipal solid waste management." Waste Management Vol. 16(5/6):pp. 341-350

Sha'Ato, R., Aboho, S.Y., Oketunde, F. O., Eneji, I. S., Unazi, G., \& Agwa, S. (2007). Survey of solid waste generation and composition in a rapidly growing urban area in Central Nigeria. Waste Management, 27(3), 352-358.

Sheppard, J. A. C. (1995). The black-white environmental concern gap: An examination of environmental paradigms. Journal of Environmental Education, 26(2), 24-35.

UNCED (1992). Report of United Nations Conference on Environment and Development (Rio de Janeiro, Brazil, A/CONF.151/26 (Vol. I). Retrieved May 23, 2008 from Web

site: http://www.un.org/documents/ga/conf151/aconf151261annex1.htm

Uwaegbulam, C. (2004). World is meeting goals of safe drinking water but falling behind on sanitation, says UN. The Guardian, Monday, August 30, 2004. P. 50.

Van Liere, K. D., \& Dunlap, R. E (1981). Environmental concern: Does it make a difference how it's measured? Environment and Behaviour, 13, 651-676.

Waste Electrical and Electronic Equipment Directive. 2002. Council Directive 2002/96/EC, Official Journal of the European Communities, L37, 24-39.

Waste Framework Directive. 1975. Council Directive 75/442/EEC, Official Journal of the European Communities, L 194, 39-41.

Waste Incineration Directive. 2000. Council Directive 2000/76/EC, Official Journal of the European Communities, L 332, 91-111.

Waste Landfill Directive. 1999 Council Directive 99/31/EC, Official Journal of the European Communities, L 182, 1-19.

Waste Online. 2004c. Legislation affecting waste [WWW] http://www.wasteonline.org.uk/resources/InformationS heets/Legislation.htm (accessed 7th July 2012).

Williams, P. (2005). Waste Treatment and Disposal, Second edition, John Wiley and Sons Ltd, Chichester, 380pp. 